\title{
Headdress Nomination: Specifics Of Imagery
}

\author{
N. M. Loktionova \\ Foreign languages Chair \\ Don State Technical University \\ Academy of construction and architecture \\ Rostov-on-Don, Russia \\ nad572@yandex.ru
}

\author{
I. A. Kuzminova \\ Foreign languages Chair \\ Don State Technical University \\ Academy of construction and architecture \\ Rostov-on-Don, Russia \\ irinagomulko@yandex.ru
}

\author{
I. A.Zubkova \\ Foreign languages Chair \\ Don State Technical University \\ Academy of construction and architecture \\ Rostov-on-Don, Russia \\ malenkii78@mail.ru
}

\author{
S. A. Kruglova \\ of philological Sciences \\ Foreign languages Chair \\ Don State Technical University \\ Academy of construction and architecture \\ Rostov-on-Don, Russia \\ svetazh@inbox.ru
}

I. A. Zhyvotkova

Foreign languages Chair

Don State Technical University

Academy of construction and architecture

Rostov-on-Don, Russia

kosheleva@list.ru

\begin{abstract}
Linguistic explication has originated a specific and very important dichotomy: "language of life - life of language" [1], which creates unlimited possibilities for interdisciplinary linguistic studies. Visions of a language are inseparable from visions of relationships between a person and the world in a given epoch, from the characteristic worldview of the time. Extended understanding of the linguistic function linked to an issue of anthropocentrism and ethnocentrism facilitates the appearance of new perspectives of philological studies. The language as a special substrate of culture, piercing it throughout, is the most important means for organizing and ordering the reality, the only key for its comprehension. The nature of the language as a whole and especially its vocabulary, being a "fast-response area" [2], directly depends on the total diversity of social phenomena. In the area of material objects there are regular and inescapable permanent changes, especially during the watershed periods in the life of a society, under new conditions of communications etc, which first and foremost find their reflection in the lexical and semantic space and its transformation.
\end{abstract}

Keywords-headdress nomination, vocabulary, lexical-semantic space, linguistic anthropology, imagery.

\section{INTRODUCTION}

Modern Russian linguistic school of thought considers problems of the language and thought through the prism of worldview creation, treating linguistic and conceptual worldviews separately. A linguistic view of the world is an "image of everything existing as an integral and multi-part world, developed by centuries-long experience of the people and implemented by the means of linguistic nomination, a world, which in its structure and linguistic links, represents, first, the person, their material and spiritual activity, and second, everything surrounding the person: space and time, animate and inanimate nature, area of man-made myths ..." [3]. This definition clearly expresses anthropocentrism of the language: it highlights creative character and dynamism of the language, determined by conscious human activity.

Cultural linguistics proceeds from acknowledging the fact that the three phenomena, namely, the language, the mindset and the culture, are organically linked, they presuppose each other and no one of them may be excluded or assumed as a dominant. Cultural linguistics, being a synthesizing science, as a sui generis area of research oriented to revealing the characteristics of links and relationships among the language, the ethnic mindset and the culture, is becoming nowadays a timely and prospective area, especially in the context of successful adaptation and integration into the intercultural space. According to V.V. Vorobyov, anthropocentrism of the cultural linguistics "corresponds to the general trend in humanities research and in linguistics in particular, turning back (from structuralism) to the human factor in the language and to a native speaker as a central figure in the communicative process" [4].

\section{OBJECTIVE}

Interplay between the language and the national culture opens a unique possibility to recreate some details of the 
historical past of an ethnos from linguistic data, and to reveal the worldview existing in the consciousness of a modern native speaker. The language reflects value systems that form foundation of different cultures, thus, phraseology of a language linked to the naïve worldview and existential experience gathered by the ethnos during several centuries is the best reflection of "stereotypes in the popular consiousness" [5].

National and cultural specifics of lexico-semantic space of the "headdress" concept is manifested in proverbs to a sufficiently complete degree. Association linked to a headdress are very rich, as evident from proverbs and adages that reflect different types of the headdress in their structure. A person unconsciously absorbs national forms of culture through the imagery of their native language. Let us treat imagery, following V.N. Teliya, as a "specific macrocomponent of semantics, formally manifesting in the internal or external form of the meaning" and preconditioning emotional semes [5].

\section{PROBLEMATICS}

In line with the issue of the language semantic process engagement into the culture-specific elements modeling, the authors' attention is drawn to the vocabulary, nominating headdress. Names of different man-made artefacts created during the evolutionary development, including those that segment the headdress semantic area, are undoubtedly of research interest. Description of headdress nominations from the position of linguistic anthropology is understandable and justified, because being directly linked to the history, way of life and culture of a nation, such vocabulary is a valuable source of data for cultural linguistic studies.

\section{MAIN PART}

Units of Russian phraseology demonstrate different attitudes to headdress in accordance with the national traditions. Together with other linguistic units, proverbial units reflect specifics of a national psyche and philosophy and ensure full-featured communication. Some idioms, proverbs and adages reflect humorous, ironic attitude to a headdress; they have colloquial tone:

- шапку в охапкy (lit. to grab one's hat) get one's stuff together fast and leave);

- шапочное / шляпочное знакомство (remote acquaintance); шапочно знакомство не пойдет 6 потомство (lit. remote acquaintance cannot be passed to heirs) ;

- с шапкой по кругу (lit. with one's hat along the circle, about fundraising); со иляпой в руке можно пройти по всей стране;

- аршин с шапкой (lit. one yard when measured together with a hat, about a short or underage person);

- $\kappa$ шапочному разбору / $\kappa$ шапкам (lit. when people are taking their hats back, to come when everything is over, be late);
- греха шляпой не покроешь (lit. one cannot cover one's sins with a hat);

- дело в шляпе (lit. the deed is in the hat, about successfully finishing a business); possibly linked to a tradition of drawing a lot from a hat, alternatively, linked to putting a bribe in official's hat;

- повесил шляпу (lit. (he) hanged his hat, to plan to stay for long);

- под шляпку заглядывать (lit. to look under a hat, to be tactless to a woman);

- женщина везде оставляет иляпу, а мужчина голову (lit. the woman leaves her hat, the man leaves his head);

- гол, да в шляпе, - тот же шляхта (lit. naked, but still in a hat, a nobleman as well);

- шапка на нем так копыл копылом и торчит (lit. his hat looks like a hoe);

- шапочка в две денежки - и та набекрень (lit. опе's the hat costs two pence but is still worn askew) and others.

Set phrases with pejorative evaluation, reflecting depreciatory, contemptuous attitude and different negative connotations are common; they are assigned with specific conceptual attributes:

- свинья в ермолке (lit. a pig in yarmulka, about a person with basic thoughts, a pejorative characteristic of an ignorant and disreputable person;

- ломать шапку (lit. to break one's hat, to bend the neck, to humble oneself, , arch. - to bow servilely);

- получить по шапке (to take a blow on one's hat);

- на воре шапка горит (lit. the hat is burning on a thief);

- под красную шапку / под красной шапкой (lit. under a red hat, arch. - to serve in the military);

- по Сеньке и шапка (lit. the hat fits Senka, on merit);

- нам ненавистны тиранов короны; терновый венеи (lit. we hate the crowns of tyrants and crowns of thorns);

- говорить сквозь шляпу - (lit. to talk through a hat) to talk nonsense;

- в голове нет - в шапку не накидаешь (lit. if there is nothing in your head, you cannot get anything in a hat);

- шапку выцграл, а кафтан проиграл (lit. won a hat, but lost a jacket);

- изари дерутся, у народа шапки летят (lit. kings fight, but people's hats are flying);

- бабы бранятся, так платки с головы валятся (lit. women are quarelling so hard, that their babushkas fall off their heads);

- носить две иляпь - (lit. to wear two hats) to work for two employers; 
- дурака узнаешь по красной шапке (lit. уои can know the fool by a red/beautiful hat) about a discrepancy between the external and the internal world) and others.

Significance of a headdress, on the verge of exaltation and admiration is reflected in many adages:

- если у человека есть голова, то должна быть и шляпа (lit. if a person has a head, one has to have a hat);

- шляпа есть самый быстрый способ заставить говорить о себе (lit. a hat is the easiest way to make other people speak about you);

- женщину в шляпке забыть нельзя (lit. it is impossible to forget a lady wearing a hat);

- шляпных дел мастер (lit. hatter) (a high esteem of professional level);

- в брюхе солома, а шапка с заломом (lit. with hay in one's stomach, but still wearing one's hat askew);

- шапка в рубль, а щи без круn (lit the hat costs one ruble, but the soup is without groats);

- без рубля - как без шапки (lit. being without a ruble is like being without a hat);

- шапочка с ушами -молодчик с кудрями (lit. an eared hat, a curly lad);

- считай баба осень с сентября по шапкам и по лаптям (lit. woman hold the autumn starting from September due to hats and bast shoes);

- без жены - как без шапки (lit. being without a wife is like being without a hat);

- «мы врагов шапками закидаем» (lit. we will bury our enemies under our hats, there are diverse contextural meanings registered: on the one hand, the hat signifies courage, lack of fear on behalf of warriors; on the other hand, it is a bravado based on the numerical superiority, following the principle: a valiant shows himself with a bayonet, a coward shows himself with his tongue);

- «кричали женщңины «ура!» и в воздух чепчики бросали» (lit. women were screaming hurray and throwing their cornettes up in air, a precedent saying, demonstrating a drift from Griboyedov's aphorism (Woe from Wit, Act II, scene 5), which was later quoted by Pushkin (The Blizzard from The Tales of the Late Ivan Petrovich Belkin) into a repository of proverbs);

- женщина из ничего может сделать три вещци: скандал, салат и ...иляпку (lit. a woman may create three things out of nothing: a quarrel, a salad and a hat) and others

The idiomatic concept of the Russian people that reflects specifics of the worldview seems to be most precisely represented in those proverbs where a specific linguistic and cultural portrayal of a headdress is given, for example:

- надень красивую иляпу на умную голову (lit. pиt а beautiful hat of your smart head);
- по шапке встречают (lit. first impressions are based on a hat);

- в шляпе, но без штанов; без порток, а в шляпе (lit. in a hat, but without trousers);

- не купил батька шапку: пусть уши мерзнут (lit. mу dad hasn't bought me a hat, so let my ears go freezing);

- джентльмена делает иляпа (lit. a hat makes уои a gentleman) ;

- пронести шляпу на ухе (lit. to carry the hat on one's ear, to trot);

- поменял шляпу - и образ мыслей поменял (lit. changed a hat, thus, changed views);

- хороша алая лента, когда на молодую надета (lit. the scarlet ribbon looks good when it is worn by a young girl) and others.

In the authors' opinion, the cultural linguistic "portrait" of a headdress gives an ability for non-trivial representation of the role of social in the language. Moreover, this approach is very close to the idea of Yu. D. Apresyan [6] about «lexicographical portrayal of a lexeme», «small monograph about a single word» (with a collection of its lexical and grammatical undertones of meaning, pragmatic additions, all sorts of connotation, including social ones). This idea has got a wide recognition in the modern linguistic science. It may be validated by the fact of its practical application in the first issues of NEDSRL (New Explanatory Dictionary of Synonyms of the Russian Language). This idea echoes the idea of L.P. Krysin [7] on sociological portrayal, which shall follow the characteristic directions of selection of linguistic features and forms of speech behavior, speech behavior stereotypical characteristic of members of different social groups, code switching due to the communicative situation and the social role of the partner, etc.

Within this framework, a study of proverbial space of the Russian language [8] from the perspective of diverse social changes is highly productive and allows characterizing typical situations and predicting a certain model of societal behavior. All the more, at the end of the 20th century the proverbial space became wider with the appearance of so-called «anti-proverbs» - modern analogues, variants and transforms of proverbs and adages, more often than not with a ludic (gameplay) function [9].

The rhymed adages note as the society breaks the norms. Democratization of the proverbial genre leads to appearance of an entire field of the anti-proverb. One of the timely tasks of the modern paremiology is to register not only traditional and new paremias, but functional and stylistic interpretations of their transforms as well [9]. It is connected to wide distribution of the anti-proverbs, but most of all to their low degree of exploration. Until now, the antiproverbs have never become an object of close attention on the part of Russian linguists, even the term itself has not stabilized yet. The following are found in literature on the subject: трансформированные пословицы (transformed proverbs), пословичные трансформы (proverb 
transforms), пословичные мутации (proverb mutations), переиначенные мудрости (distorted wisdoms), индивидуально-авторские преобразования (individual and author's transformations). All the terms, functioning in the language, are attempts to assess this linguistic feature and understand its lignuistic and social nature. The Dictionary of Synonyms of V.N. Trishin contains the following definition: «anti-proverb - noun, number of synonyms: 2 - anti-adage - cracker [10]. This explanation, which is the only one currently existing, is treated as irrelevant, superficial and not offering a complete understanding of anti-proverb as a linguistic feature.

To research the anti-proverb field and to determine specifics of the imagery in the semantic content of headdress nomination among students, a social linguistic experiment was carried out, thus uncovering a certain lexical layer connected in one way or the other to the concept of headdress. The following transformed adages were obtained for well-known proverbs, adages and aphorisms:

- на женские прихоти / причуды не напасешься; на женский нрав не угодишь / не утрафишь; женских nрихотей не перечтешь (lit. уои cannot collect enough to cover all feminine whims) (В. Даль) - на женские иляпки не наnacembcя (lit. you cannot collect enough to cover all the bonnets) (embodiment of feminine capricious and contradictory nature and elevated exigence);

- всех дел не переделаешь (lit. уои cannot complete all the deeds) - всех иляп не переносишь (lit. уои cannot wear all the hats);

- семь раз отмерь - однова отрежь (lit. measure seven times and cut once) (В. Даль) - семь раз померь - один paз куnu (lit. try on seven times and buy once) (about excessive haste which does not bring expected positive results);

- думают думу без иуму (lit. one thinks without any noise) (В. Даль) - думают думу без шапки, - шапка dyмamb мешаem (lit. one thinks without a hat on, for the hat impedes thinking) (about rationality and consistency of actions linked to mental activity);

- не всяку думку при людях думай (lit. not every thought shall be thought in public) (В. Даль) - не всяку думку в шапке думай (lit. not every thought shall be thought while wearing a hat) .

Appearance of such anti-proverbs as:

- думкою дурки богатеют (lit. fools get rich in their thoughts) (В. Даль) - думкою дурки богатеют, а умные шапкой (lit. fools getting rich in their thought, smart people get rich and buy a hat) ;

- одна голова хорошо, а две лучше (lit. one head is good, two heads are better) - ум хорошо, а шапка зимой лучше (lit. a sound mind is good, but a hat in the winter is better),

is the evidence of transformation in the social values, when today's reality demonstrates growing realization of inherent worth of an individual and a right for independent choice of behavior to elevate one's comfort level without reference to public morals. Different contexts form various connotative increments and facilitate appearance of new pragmatic co-meanings.

It is worth noting that the Russian proverbial field is rich in paremias connected to mental abilities on the scale of: smart / stupid. As smarts are connected to a head, many transformations employ associative links to a headdress:

- подумаешь умом, и шапка слетит (lit. think with your mind, and your hat goes off);

- умная мысля приходит в шапке (lit. a smart thought comes when you are wearing a hat);

- мужик должен иметь голову, а женщина - шляпку (lit. a man shall have a head, while a woman shall have a bonnet) .

A widely known «не по Сеньке шапка» (lit. this hat does not fit Senka) and «каждый метит в Наполеоны» (lit. everyone wants to be a Napoleon), are transformed into a complex syntactic structure: «каждый метит $в$ Наполеоны, но не каждому его шапка по размеру...» (lit. everyone wants to be a Napoleon, but his hat doesn't fit everyone).

Reaction to modern changes, like demolitions of small commercial buildings in different Russian cities, including Moscow, was reflected in a transformation: «на каждый ларек не накинешь платок» (lit. уоu cannot cover every kiosk with a handkerchief, from "на каждый роток не накинешь платок", lit. уоu cannot cover everybody's mouth with a handkerchief).

Some anti-proverbs connected to the concept of headdress are registered in dictionaries compiled by $\mathrm{H}$. Walter, V.M. Mokiyenko [9]:

- тяжела ты, шапка Мономаха (lit. Monomakh's Cap is heavy);

- тяжела ты бригадирская кепка (lit. foreman's cap is heavy);

- на воре шапка горит, а на пиве - выпить велит (lit. the hat is burning of a thief, and advises to drink when it sees beer) ;

- из спасибо шапки не сошьешь (lit. a "thank уои" cannot be used to make a hat);

- на воре и шапка глаза колет (lit. it is painful to look at the thief's hat);

- хочешь, чтобы перед тобой снимали шляпу, иди в гардеробщики (lit. if уоu want others to remove their hats in front of you, start working as a cloakroom attendant) ;

- ноги в тепле, а голова в кепке (lit. feet in a warm place, head in a cap) and others.

The transforms of well-known Russian proverbs given above may have different motivational and conceptual nature: from principal denial of a truism to pure linguistic 
wordplay. Despite the very wide functional range of such wordplay, all its registers are parts of the laughter culture, analyzed by literature scholars and linguists (Bakhtin 1965; Likhachyov, Panchenko 1976 and others). In new conditions of immediate distribution of information through media and Internet, the laughter culture has particular aspirations for priority and linguistic novelty. However, it is worth noting that specifics of imagery in all the anti-proverbs given above lies in a specific implicit meaning, oriented towards indirect / hidden motivation of speakers and semantically largely corresponds to the original, that is, traditional proverbial repository. But it gets a new interpretation of information previously obtained to adapt the society to a certain situation.

Lately, the new term антипословица (anti-proverb) infiltrated the Russian language as several variants: антикрылатое слово (anti-proverbial expression), антикрылатое выражение (anti-proverbial saying). At that, it is necessary to notice that these terms are used to collections of relevant paremias published in Europe. Specialized linguistic studies of Russian anti-proverbs has just started. The authors suppose that transformations of proverbs shall undergo thorough analysis with the aim of their further characterization, but the main factor for their use shall be keeping to aesthetic sense and respect to the national language as a cultural treasure.

Another interesting direction in the study of semantic features of headdress nomination and its imagery is study of ethnic mentality in different linguistic cultures and subcultures. Attitude of Russians towards a headdress correlates with other linguistic cultures in the most important semantic indicators. One may note a special attitude towards these culture-specific elements in English and French linguistic cultures. For instance, in the English linguistic culture:

- I'll eat my hat - correlates with Russian голову даю на отсечение (lit. I can give my head for being cut off);

- if the cap fits, wear it - если шапка впору, то носи её (if you take sombody's words personally, then they have at least a grain of truth);

- his hat covers his family - его шляпка прикрывает всё его семейство (a lonely man);

in French linguisitc culture:

- mettre chapeau bas - to remove one's hat (to recognize other's supremacy);

- enfoncer son chapeau - to pull one's hat over one's eyes (to take courage);

- tirer son chapeau - to remove one's hat (as a sign of admiration) and others.

Semantic increments, revealed in the idioms and proverbial repository (proverbial space) may be held universal and characteristic for linguistic representation of the concept of headdress. The lexical background of headdress nominations includes additional connotative meanings of diverse types: emotional assessment, axiological assessment, expressive, stylistic and other. Internal motivation of such nominations is intertwined with pragmatic level with conscious intention for effective influence in colloquial medium. The pragmatic component of the meaning of nomination is made active and determined by its connotative potential, being formed during the operation in the language and the level of precedence, which is given to the nomination in the linguistic image of the world (worldview). Anthropogenic role of a headdress predefines its characterizing function, where names of headdress explicitly and implicitly contain pragmatic components that characterize contextually activated appearance and inner world of a person, the owner of a headdress.

For instance, the lexeme шляпа (brimmed hat) contextually may obtain different meanings. In just one context - снимаю шляпу (lit. I take my hat off)- there are two perceptions and attitudes towards this object: 1) direct meaning of greeting, determined by etiquette; 2) a sign of special admiration, respect, gratitude in assessment of actions. Besides, there is an opposite representation registered: эх, ты шляпа (you are a hat), прошляпить - in the meaning to miss something important; a saying addressed to a hapless person. The lexical unit иляпа gets a pejorative assessment in such a context.

Different other instances of contextual usage formed under influence of different subjective and objective value, sound bright and original:

- напялить шляпу (to wear a hat) - meaning that something does not fit a person, especially if this person tries to be original;

- not just put a hat on, but облачиться, натянуть; таскать, нахлобучить one and the same headdress; стягивать, стаскивать a headdress;

- обнажить голову (lit. to bare one's head) , pасхаживать в шляпе (lit. to walk in a hat) - to appear important;

- иляпу сними (lit. take off your hat ) - meaning "don't try to appear smart", due to the fact that a brimmed hat (unlike a cap) is associated with an intelligent person, a gentleman.

It is necessary to note that lexical co-occurrence of the studied nominations has a certain specifics. The most numerous are co-occurences of concrete nouns naming different types of headdress with descriptive adjectives characterizing these objects in different ways. This parameter shows almost total coincidence with characteristics of clothing items in general. Co-occurrence range of this lexical units is somewhat narrower for verbs serving the clothing vocabulary group, due to a certain specifics of the nominated object (e.g., odemb / надеть, носить / износить, снять / сбросить, оставить / забыть, отремонтировать / отреставрировать, почистить / постирать, обновить, купить / получить в подарок, повесить, менять, заказать, ходить etc, but these limitations are insignificant and have no principal significance. 
Other types of headdress may get negative connotations as well: ушанка (ear-flaps hat) - is a symbol of coutryside; a wearer of babushka is emphatically named Дуня, Дунька, Маруся, Фекла (female names more popular among rural dwellers than among urbanites), деревня (village), колхоз, колхозница (member of collective farm). While recently, due to a "fashionable retro" trend, there is a certain semantic shift registered, manifesting in recognition of certain headdress as fashionable and ultramodern (for example, шапка-ушанка; волкошапки (wolf-hat) - a new characterizing nomination of a headdress, created under the direction of E. Volkova, an actress, whose last name is connected to wolfs, - it is a picturesque brand, reminding of Russian folk imagery).

There are some pragmatic increments obtained by both names of the headdress (e.g., nomination of young-adults specific headdress) and their family of words with figurative meaning (e.g., прийти к шапочному разбору, шиляпных дел мастер, быть под колпаком, околпачить, покрылеввать etc.). Let us assume that appearance of additional, often negative, connotations in certain contexts is motivated by attitude towards the headdress as an important component of any attire; moreover, the ancient concept about uncovered had, linked to both health (one's head and feet shall be held in warm) and rituals.

Even the way to wear a headdress in the perception of native Russian speakers has a certain characterizing function, revealing a person's inner world. For example, надвинутый на лоб головной убор (one's hat moved to one's forehead) may symbolize different things: being retired into oneself, solitude, a wish to stay unrecognized, etc. A hat moved aside, "with a tilt, moved to one's ear" [11] paints a completely different picture in the Russian collective consciousness: thoughtless, reckless, hotheaded, etc.

\section{CONCLUSION}

Thus, the research of semantic space of the headdress nominations with the aim to reveal specifics of their imagery has shown that, without using a wide cultural linguistic context, including proverbial repository, it is impossible to comprehend pragmatic and socio-cultural nature of such nominations, their expressive, stylistic and connotative diversity in the modern paradigm of scientific knowledge.

\section{References}

[1] L.Yu. Buyanova, E.G. Kovalenko, Russian idiom as a mental and cognitive means of linguistic conceptualization of moral qualities of a person: a monograph, 3rd edition, stereotypical, Moscow: Flinta: Nauka, 2013.

[2] E.D. Polivanov, Introduction to Linguistics, Moscow: KomKniga, 2006. 232 p.

[3] N.Yu. Shvedova, Russian Language. Selected Works, Russian Academy of Sciences; Department of historical and philological sciences; Institute of the Russian Language named after V.V. Vinogradov, Moscow: Yazyki Slavyanskoy Kultury, 2005, p. 15.

[4] V.V. Vorobyyov, Cultural Linguistics: a monograph, Moscow: RUDN, 2008, p. 88.

[5] D.N. Teliya, Russian phraseology: Semantic, pragmatic and cultural linguistic aspects, Moscow: Shkola Yazyki Russkoy Kultury, 1996, 288 p.

[6] Yu.D. Apresyan, Selected Works. Integrative Desctiption of Language and Systemic Lexicography, Moscow: Yazyki Russkoy Kultury, 1995, In 2 vols, vol. 2, $767 \mathrm{p}$.

[7] Krysin L.P. Explanatory Dictionary of Foreign Words, Moscow: Eksmo, 2007. 944 p.

[8] Levin Yu. I. Selected Works. Poetics. Semiotics, Moscow: Yazyki Russkoy Kultury, 1998, pp. 483 - 503

[9] Walter H., Mokiyenko V.M. Anti-proverbs of the Russian, Saint Petersburg: Neva, 2005.

[10] V.N. Trishin, Large Reference Dictionary of the Russian Synonyms, ASIS.

[11] D.N. Ushakov, Large Thesaurus of the Modern Russian Language, Moscow: Slovari Russkoy Kultury, 2008, p. 479.

[12] N.Sh. Aleksandrova, "Native Language, Second Language and Linguistic Phenomena Without a Name," Voprosy Yazykoznaniya (Issues in Linguistics), No. 3, 2006.

[13] V.M. Alpatov, "What and how does the linguistics study?," Voprosy Yazykoznaniya (Issues in Linguistics), No. 3, 2015.

[14] V.B. Gulida, Conference «Popular Linguistics»: Opinion of Native Speakers About the Language, Voprosy Yazykoznaniya (Issues in Linguistics), No. 5, 2013.

[15] M.Yu. Pupynina, A.A. Syuryun, Conference "Systematic Changes in Languages of Russia," Voprosy Yazykoznaniya (Issues in Linguistics), No. 4, 2015. 